\title{
Local governance, private investment and economic growth: The case of Vietnamese provinces
}

\author{
SU DINH THANH \\ University of Economics HCMC - dinhthanh@ueh.edu.vn \\ BUI THI MAI HOAI \\ University of Economics HCMC - maihoai@ueh.edu.vn
}

\begin{abstract}
ARTICLE INFO ABSTRACT
Article history:

Received:

May 26, 2017

Received in revised form:

Oct. 17,2017

Accepted:

Oct. 25,2017

Keywords:

The study examines the role of local governance in the relationship between private investment and economic growth at provincial level in Vietnam. The study data consists of 63 Vietnamese provinces in the period of 2005-2013. Provincial Competitiveness Index (PCI) is a proxy for local governance. Estimated by two-step System Generalized Methods of Moments, the study shows interesting results. First, local governance and private investment have significant effects on economic growth. Second, the growth effect of private investment is strengthened when interacted with the high level of PCI. Third, interacting PCI sub-indices with private investment, the results show that some aspects of PCI are still barriers to the growth effect of private investment, namely entry cost, time cost, informal charges, and policy biases. Our findings suggest that local governments should make local governance better to improve the growth effect of private investment.
\end{abstract}

Local governance

Private investment

Economic growth

Sys-GMM estimation 


\section{Introduction}

Institutions are the rule of game in a society and imposes market rules or constraints on human behaviors (North, 1990; North \& Thomas, 1973). Public governance refers to how public policies are made in the framework of institutions (Kaufmann \& Kraay, 2002). Public governance affects economic performance because it is related to asymmetric information, transaction cost, and risk. Various recent studies have investigated the relationships among governance and economic growth (Aguirre, 2017; Kloosterman \& Schotter, 2016; Yıldırım \& Gökalp, 2016; Putterman, 2013; Marangos, 2008). However, most these studies ignore private sector as a channel to transmit governance effect to economic performance. Second, the literature on the growth effects of private investment in terms of governance is quite large and complicated in nature and needs to be further clarified. Third, studies observing the growth effects through the relationships between governance and private investment at provincial level in a country are scarce.

The economic reforms originated from the late 1986s have directed to meliorate governance and augment opportunities for private sector development. Up to now, Vietnam has moved closer to ASEAN countries and international communities through its integration into regional and global economy (Gates, 2000; Schmidt, 2004). The main content of these reforms has focused on building a democratic, strong, clean, professional, modernized, effective and efficient public administrative system (Vasakui et al., 2009; UNDP, 2009). As a result, Vietnam's private sector has become progressively momentous to economic growth. For example, according to Vietnam' GSO, Vietnam's private sector has a significant contribution to nearly $40 \%$ GDP and $30 \%$ of total budget revenue in
2016. However, there remain continual challenges that limit the role of Vietnamese government in support of private sector. Private sector performance and institutions seem be fragmented, leading an efficiency loss in resource allocation. Underlying market economy institutions related to fair legal implementation, corruption control, transparency are still barriers to private investment (ADB, 2005; Schaumburg-Müller, 2005; Anh et al., 2016; Tromme, 2016).

It is assumed that Vietnamese local government has played a critical role in supporting private sector and promoting local economic growth. Our motivations are twofold. First, previous studies have examined the relationship between institutions or private investment and economic growth (see Tridico, 2007; Tavares, 2004; de Haan, 2007; Glaeser et al., 2004; Yıldırım \& Gökalp, 2016). However, most previous studies have ignored the role of governance in the growth effects of private investment. In addition, the nexus of governance and private sector development in Vietnam is still controversy. Han and Baumgarte (2000) document that Vietnamese private sector has reservations about business environment, especially legal institutions and administrative reforms. Nguyen and van Dijk (2012) find that weakness in local governance, especially corruption is still a barrier to the growth of private investment. In this vein, Tran et al. (2009) show that public administration deficiency and judiary system are detriment to private sector development. In contrast with these studies, Nguyen et al. (2013) shows local governance reforms have a significant contribution to improve Vietnamese firms' performance. This study investigates the role of local governance in affecting the growth effect of its interaction term with private investment. Provincial Competitiveness Index (PCI) is a proxy for provincial governance. PCI is assumed to be 
linked to the efforts of provincial public administration reforms in assessing a various aspect of provincial dynamic and public services delivery. It is expected that better PCI makes its effect on private investment being positive. Second, the study uses PCI sub-indices to detect the growth effects of private investment at provincial level. The study considers interaction terms of PCI sub-indices with private investment are helpful to better understand the kinds of incentives and costs that are required to improve provincial governance in order to increase the growth effect of private investment. PCI subindices include several dimensions of provincial economic governance: entry cost for new firms, land access, transparency, time costs of regulatory compliance, informal charges, proactivity of provincial leadership, policy bias, labor training and legal institution.

This study applies the two-step system generalized methods of moments estimation to a dynamic panel data set of 63 Vietnamese provinces for the period of 2003-2013. The strategy for this research is as follows. First, the study investigates the growth effects of PCI and private investment. The study uses the average level of the whole PCI sample as criteria to classify provincial governance quality into low level $\left(P C I_{1}\right)$ and high level $\left(P C I_{2}\right)$. Second, the study interacts PCI (including $P C I_{1}$ and $P C I_{2}$ ) with private investment to predict the role of PCI in promoting economic growth. Third, the study also examines the growth effects of interacting PCI sub-indices with private investment. The research findings contribute to the literature by highlighting the roles of local governance in promoting economic growth.

The remainder of the paper is organized as follows. Section 2 provides a literature review on the relationship between public governance, private investment and economic growth. The research model is presented in section 3 . The research data are described in section 4 . The methodology is mentioned in section 5. The empirical results are analyzed in section 6 . Section 7 outlines conclusions.

\section{Literature review}

The institutions are defined as game rules in a society (North, 1990a), which can set constraints on human behavior (North, 1981; Acemoglu \& Robinson, 2008). Institutional theory emphasizes that institution as fundamental determinants of long-run growth, which explains the residual differences in economic growth between countries based on differences in human capital, physical capital, technological progress, and other economic factors (Acemoglu \& Robinson, 2008; Branch, 2014; Busse \& Hefeker, 2007; Duncan, 2014). Institutional quality reduces asymmetric information problems, transaction cost, and risk, while it increases market efficiency and asset allocations, and protects property rights (Williamson, 1981; Cohen et al., 1983; Ho \& Michaely, 1988). Public institution is generically the so-called public governance that determines how government and public agents run a country (Kaufmann et al., 2000; North, 1990b; Brousseau et al., 2011). Public governance, thus, is critical for improving the efficiency of government activities because it could change incentives for economic agents in allocating public resources. Measuring public governance is relatively complicated. Governance quality can be measured via six institutional indicators: (1) voice and accountability, (2) political stability and absence of violence/terrorism, (3) government effectiveness, (4) regulatory quality, (5) rule of law, and (6) control of corruption (Kaufmann et al., 2004; Cooray, 2009; Kaufmann et al., 2011). Governance quality can also be measured by the level of democracy (Barro \& Sala-i-Martin, 1992; Acemoglu et al., 2008). 
In the existing literature, studies on the relationship between governance and economic growth have increasingly developed. The impacts of the total level of governance and governance components on economic growth performance are investigated in existing empirical studies (see Olson et al., 2000; Gerry et al., 2010; Sarker \& Rahman, 2007; Markus \& Mendelski, 2015; Wilson, 2016; Rajkumar \& Swaroop, 2008; Cooray, 2009; Attila, 2009). Rajkumar and Swaroop (2008) find that poor quality of governance cannot improve economic performance in 91 countries over three years (1990, 1997, 2003). Cooray (2009) undertakes an empirical study of 71 countries from 1996 to 2003 and indicates that the quality of governance plays an important role in economic growth. Attila (2009) shows that while corruption may encourage economic growth, it also has a negative impact on the tax rate; however, in the long term, corruption can be harmful to economic growth in 90 countries from 1980 to 2002. Economists seek to explore the possible channels via combining public spending and governance to explain their impacts on economic performance (see Butkiewicz \& Yanikkaya, 2011; d'Agostino et al., 2016; Dzhumashev, 2014; Cooray, 2009; Farag et al., 2013; Aizenman \& Glick, 2006; Devarajan et al., 1996). Aizenman and Glick (2006) employ the interaction of government quality and military spending and find that it changes the impact of military expenses on economic growth. Cooray (2009) uses the interaction between the governance quality dummy variable and government expenditure to evaluate the growth effect of governance quality and government expenditure. In addition, d'Agostino et al. (2016) analyze the interaction between corruption and government spending to explain the extension of the production function based on the arguments of Barro (1990) and Devarajan et al. (1996).

The role of governance in promoting private investment is widely recognized in the academic literature and policy practices (Kshetri \& Dholakia, 2011). Since private firms suffer some risks in their investment and businesses, the government must support and share risks. Governance with property rights protection and transaction cost reduction is important for private investment growth (Kshetri \& Dholakia, 2011; Peev, 2015; Krasniqi \& Desai, 2016). Good governance helps build trust and provide rules and stability that are necessary for firms to develop their businesses in the long run. Moreover, it creates productive interaction between government, public agents and firms and then the Nash equilibrium is achieved in offering the highest social welfare (Kousky et al., 2006). On the contrary, weak governance deteriorates investment environment and increases risks related to private investment decisions. Barro, (1991) indicates a negative linkage between political violence and private investment. Morrissey and Udomkerdmongkol (2012) find that corruption and political instability are the main cause of being harmful to private investment. Percoco (2014) emphasizes that better institution, related to civil freedom, better regulatory framework, and lower corruption, increase private participation in private-public partnerships. Jiang et al. (2015) present that multinational enterprise investments in emerging countries depend on host government's governance structure. Braga Tadeu and Moreira Silva (2013) highlight that economic stability and government's credibility are determinants of long run private investment growth in Brazil. Ng and Yu (2014) show that weak proper rights institutions are among main causes to diminish firm productivity in China. Acknowledging these issues, we believe that governance is expected to enhance economic growth by promoting private investment's marginal productivity.

For Vietnam, the relationship between 


$$
\begin{aligned}
& G P P G_{i t}=L G P P_{i t}-L G P P_{i t-1}=\alpha_{1} L G P P_{i t-1}+\alpha_{2} D P I_{i t}+\alpha_{3} P C I_{i t}+\alpha_{4}\left(D P I_{i t} \times P C I_{i t}\right) \\
& +\alpha_{5} Z_{i t}+\left(\gamma_{i}+\varepsilon_{i t}\right)
\end{aligned}
$$

institutions and firm's performance at provincial level has received much attention from empirical studies. Using PCI 2006, Tran et al. (2009) indicate that improvements in providing market information, land access and labor training impact positively firm performance. However, defectiveness in the judiciary system and administrative services are detriminent to private firm development. By using some aspects of PCI (such as the costs of new business entry, land access, and private sector development policies), Nguyen and van Dijk (2012) provide evidence that provincial economic governance only favors state own enterprises, but a main cause of corruption that distorts business environment. Dang (2016) adds that corruption affects negatively private investment, employment and per capita income in Vietnamese provinces. Using PCI 2005-2006, Nguyen et al. (2013) and Tran et al. (2009) show that PCI sub-indices moderate export strategy and firm performance, particularly encouraging domestic firms toward their business strategy innovations in order to be more effective in competing with foreign firms. Malesky and Taussig (2009) find that PCI is positively related to foreign direct investment in Vietnamese provinces. However, the role of PCI in improving economic performance at the provincial level seems still ambiguous. McCulloch et al. (2013) argue that there are hardly any significant relations between almost all aspects of PCI and private investment. ADB (2005) and Schaumburg-Müller (2005) argue that the legal and regulatory framework for doing business lacks reliable mechanisms for resolution of commercial disputes. Vietnam's private sector has limited access to key resources and the market protections.

\section{Empirical model, data and methodology}

\subsection{Empirical model}

To estimate the growth effect of local governance and private investment, the dynamic regression is given by: where: $i$ is for the province, $t$ is for the time period, $\gamma$ is a vector of provincial fixed effect specific, $\varepsilon$ is the error term, $\varepsilon_{i t} \sim$ i.i.d $\left(0, \sigma_{\varepsilon}\right)$.

Provincial economic growth $(G P P G)$ : This is calculated by the difference of $L G P P$, in which $L G P P$ is the logarithm of gross provincial product $(G P P)$.

Provincial domestic private investment growth (DPI): This is measured by the logarithm of provincial domestic private investment. Private investment is hypothesized as a function of growth; thus an economy with a higher income per capital growth is associated with higher private investment growth (Greene and Villanueva, 1991; Oshikoya, 1994). Several empirical studies find that private investment rate is positively related to real GDP and income per capital (Sineviciene and Railiene, 2015; Morrissey and Udomkerdmongkol, 2012; Oshikoya, 1994; Greene and Villanueva, 1991). Mallick (2013) shows that private investment has a positive impact on regional development in India, whereas Luo (2007) argues that private sector has no direct effect on economic growth in China.

Provincial competitiveness index (PCI): This is used as a proxy for provincial economic governance with sub-indices: entry cost for new 
firms (ENTRYCOST); land access (LANDACCESS); transparency (TRANSPA); time costs of regulatory compliance (TIMECOST); informal charges (INFORMALCHARGES); pro-activity of provincial leadership (PROACT); policy bias (POLICYBIAS); labor training (LABORTRAIN); and legal institutions ( $L E G A L)$. There are many empirical studies using PCI as a proxy for institutions in Vietnam (see Tran et al., 2009; Nguyen and van Dijk, 2012).

A set of control variables (Z), including: (i) The growth of total provincial labor force (LABOR): Measured by logarithm of total provincial labor force; (ii) Provincial foreign direct investment growth (FDI) measured by the logarithm of provincial foreign direct investment; (iii) Provincial public spending (GOVSP); (iv) the growth of provincial human capital stock $(H C)$ that is measured by logarithm of provincial annual college and university enrollment; (v) provincial infrastructure development (INFRA) that is a proxy for the logarithm of provincial telephone lines per 1000 population; (vi) the growth of provincial exports $(E X)$ that is measured by logarithm of provincial exports; (vii) provincial inflation rate (INF) is measured by provincial consumer price index. These variables are tested in empirical studies to identify determinants of private investment and economic growth performance (see Greene and Villanueva, 1991; Oshikoya, 1994; Braga Tadeu and Moreira Silva, 2013; Jongwanich and Kohpaiboon, 2008; Villaverde and Maza, 2012; Gould and Ruffin, 1995).

\subsection{Data}

Regarding Vietnam's governance reforms, the Vietnamese government has initiated Public Administrative Reforms (PAR) Master Program in the phase 2001-2010 and in the phase 2011-2020 ongoing. The tasks of PAR are (i) institutional reform; (ii) reform of administrative procedures; (iii) development of civil servant quality; (iv) public finance reform; and (v) modernization of public administration. In the context of PAR progress, under the support of United States Agency for International Development (USAID), Vietnam Chamber of Commerce and Industry (VCCI) has developed Provincial Competitiveness Index (PCI) as a measurement of economic governance to provide assessment feedback of the private sector on how provincial government performs. PCI was first introduced in 2005, and employed for ranking 47 provinces. From 2006 ongoing, 63 provinces of Vietnam have been included in the ranking list. The overall PCI score is calculated by a weighted sum of sub-indices, in which weights are determined by the importance of each sub-index in assessing various aspects of firm performance governance in each province (USAID/VNCI-VCCI 2005, 2009). The 2005 PCI only comprised 8 sub-indices to explain differences in economic development between provinces (USAID/VNCI-VCCI, 2005). After that, the sub-indices of the PCI have been adjusted and updated in order to meet changes in Vietnam's business environment. The 2009 PCI has nine sub-indices (USAID/VNCI-VCCI, 2009). The 2013 PCI is conducted based on ten subindices (USAID/VNCI-VCCI, 2013), in which nine sub-indices of the 2009 PCI is replicated. For this reason, the study uses nine unified sub-indices to estimate effects of economic governance on provincial economic growth.

Data for this study are panel data on 63 provinces for the period of 2005-2013. Crosssections and time series are chosen to accommodate data availability from General Statistics Office of Vietnam. We define and calculate the variables in our estimations, which are summarized in Table (1). For main variables, the average growth of gross provincial product (LGPP) is 9.78; overall weighted average PCI is $56,706 \%$; the average growth of private investment is $8.223 \%$. 


\section{Table 1}

Definitions and descriptive statistics of variables

\begin{tabular}{|c|c|c|c|c|c|c|}
\hline Variables & Definition, description, and source & Obs & Mean & $\begin{array}{l}\text { Std. } \\
\text { Dev. }\end{array}$ & Min & Max \\
\hline $\begin{array}{l}\text { Provincial economic } \\
\text { growth }(G P P G)\end{array}$ & Difference of log of gross provincial product, from GSO in Vietnam & 567 & 9.792 & 1.041 & 6.964 & 13.547 \\
\hline $\begin{array}{l}\text { Provincial domestic } \\
\text { private investment }(D P I)\end{array}$ & Log of provincial domestic private investment, from GSO in Vietnam & 567 & 8.223 & 1.061 & 4.425 & 12.054 \\
\hline $\begin{array}{l}\text { Provincial public } \\
\text { spending }(\text { GOVSP \%) }\end{array}$ & $\begin{array}{l}\text { Total provincial government expenditures (including investment } \\
\text { expenditure and current expenditure that are financed from provincial } \\
\text { assigned revenue) as a percentage of GPP, from GSO in Vietnam }\end{array}$ & 567 & 8.997 & 5.768 & 0.190 & 40.514 \\
\hline $\begin{array}{lr}\text { Provincial } & \text { government } \\
\text { employees } & \text { size } \\
(\text { GOVLABORSIZE \%) }\end{array}$ & $\begin{array}{l}\text { Total provincial government employees as a percentage of total provincial } \\
\text { labor forces, from GSO in Vietnam }\end{array}$ & 567 & 5.668 & 1.724 & 2.102 & 15.208 \\
\hline $\begin{array}{l}\text { Provincial } \\
\text { competitiveness } \\
(P C I)\end{array}$ & $\begin{array}{l}\text { Entry cost (ENTRYCOST) measures the time it takes firms to register a and } \\
\text { receive necessary licenses to start a business }\end{array}$ & 545 & 7.701 & 1.051 & 3.641 & 9.598 \\
\hline
\end{tabular}




\begin{tabular}{|c|c|c|c|c|c|c|}
\hline Variables & Definition, description, and source & Obs & Mean & $\begin{array}{l}\text { Std. } \\
\text { Dev. }\end{array}$ & Min & $\operatorname{Max}$ \\
\hline & $\begin{array}{l}\text { Land access (LANDACCESS) measures the access to land for firms (easy } \\
\text { and security) }\end{array}$ & 545 & 6.379 & 0.911 & 3.036 & 8.841 \\
\hline & $\begin{array}{l}\text { Transparency (TRANSPA) measures whether firms have access to necessary } \\
\text { planning and legal documents to run their business }\end{array}$ & 545 & 5.688 & 0.987 & 2.154 & 8.854 \\
\hline & $\begin{array}{l}\text { Informal charges (INFORMALCHARGES) measures how much firms have } \\
\text { to pay for informal charges }\end{array}$ & 545 & 6.463 & 0.881 & 3.375 & 8.942 \\
\hline & $\begin{array}{l}\text { Pro-activity of provincial leadership (PROACT) measures the pro-activity } \\
\text { of provincial leadership in implementing policy and promoting private } \\
\text { sector development within national legal work frame }\end{array}$ & 545 & 5.156 & 1.448 & 1.387 & 9.388 \\
\hline & $\begin{array}{l}\text { Labor training ( } L A B O R T R A I N) \text { measures the provision of labor exchange } \\
\text { services, the ratio of trained labor forces and satisfaction with labor }\end{array}$ & 504 & 5.018 & 0.975 & 1.842 & 9.596 \\
\hline & $\begin{array}{l}\text { Legal institutions ( } L E G A L) \text { measures the implementation of legal system } \\
\text { by provincial court judge and firm confidence in legal system }\end{array}$ & 504 & 4.723 & 1.170 & 1.995 & 7.340 \\
\hline $\begin{array}{l}\text { Provincial labor force } \\
(L A B O R)\end{array}$ & Log of total provincial labor force, from GSO in Vietnam & 567 & 6.432 & 0.563 & 5.088 & 8.290 \\
\hline
\end{tabular}




\begin{tabular}{|c|c|c|c|c|c|c|}
\hline Variables & Definition, description, and source & Obs & Mean & $\begin{array}{l}\text { Std. } \\
\text { Dev. }\end{array}$ & Min & Max \\
\hline $\begin{array}{l}\text { Provincial human capital } \\
\text { stock }(H C)\end{array}$ & $\begin{array}{l}\text { Log of provincial annual college and university enrollment, from GSO in } \\
\text { Vietnam }\end{array}$ & 554 & 8.781 & 1.575 & 4.875 & 13.444 \\
\hline $\begin{array}{l}\text { Provincial infrastructure } \\
\text { development }(I N F R A)\end{array}$ & $\begin{array}{l}\text { Log of provincial telephone lines per } 1000 \text { population, from GSO in } \\
\text { Vietnam }\end{array}$ & 567 & 5.173 & 0.788 & 2.302 & 7.822 \\
\hline $\begin{array}{l}\text { Provincial inflation rate } \\
\text { (INF) }\end{array}$ & Provincial consumer price index, from GSO in Vietnam & 567 & 111.217 & 6.081 & 99.18 & 140 \\
\hline
\end{tabular}




\subsection{Methodology}

When estimating $\mathrm{Eq}(1)$, there are some serious difficulties with fixed effects model, leading to biased results. First, most variables on the right side of Eq (1) may be endogenous. The literature on the role of government in economic growth shows that government spending and governance are endogenous (Law et al., 2013; Abu-Bader \& Abu-Qarn, 2003). Other variables (such as DPI, FDI, INF, and EX) are likely to endure causality bias (Fayissa \& Grill, 2016). Second, in the context of a dynamic panel data model with a lagged dependent variable ( $\left.L G P P_{i t-1}\right)$, since $L G P P_{i t-1}$ is a function of $\gamma_{i}$ , it follows that $G P P G_{i t-1}$ is also a function of $\gamma_{i}$. Therefore, the variable $L G P P_{i t-1}$ is correlated with the error term. Nickell (1981) shows that with a technical consequence of the within transformation $N$, the lagged dependent variable ( $L G P P_{i t-1}$ ) increase standard errors. The resulting correlation creates a large-sample bias when estimating the coefficient of the lagged dependent variable, which may be not mitigated by increasing $N$ (Nickell, 1981). If the regressors are correlated with the lagged dependent variable to some degree, their coefficients may be seriously biased. Moreover, there is especially problematic in the case of data with a small time dimension. Cross-section estimates would produce a bias that is caused by the correlation between the lagged dependent variable with the unobserved individual effects because the present value of the dependent variable would itself be dependent on the individual effects, which may disappear in samples with a large time dimension. The alternative would use any type of fixed effect technique, eliminating time-independent effects by taking some kind of difference (for example first differences, within-group transformations, etc.). By first differencing the fixed individual effect is removed because it does not vary with time. In this case, however, the error term would have some lags and therefore will be correlated with the lagged dependent variable, leading to biased estimates. Several methods have been proposed in the literature (see Anderson \& Hsiao, 1982; Arellano \& Bond, 1991; Blundell \& Bond, 1998).

Arellano and Bond (1991) propose difference GMM estimator that is more efficient than the Anderson and Hsiao (1982) estimator. GMM estimator deals better with endogeneity, heteroscedasticity, and serial correction because it is specifically designed to capture the joint endogeneity of some explanatory variables through the creation of a weight matrix of internal instruments, which accounts for serial correlation and heteroscedasticity. GMM estimator requires one set of instruments to handle endogeneity and another set to deal with the correlation between lagged dependent variable and the error term. The instruments include suitable lags of the endogenous variables and the strictly exogenous regressors. This estimator technique easily generates many instruments, since by period $T$ all lags prior to might be individually considered as instruments. However, a big problem of the Arellano-Bond difference GMM estimator is that the variance of the estimates may increase asymptotically and create considerable bias. Blundell and Bond (1998) and Blundell et al. (2000) show that estimation in first differences has a large bias and low precision, even in studies with a large number of individuals $(\mathrm{N})$. The poor performance of difference GMM estimator can be worse with the degree of persistence of series because as persistence increases, lagged levels can be less correlated with current first differences, so they become weak instruments (Soto, 2009). The system GMM estimator is likely to present the best features in term of a 
small sample. Provided that series are moderately or highly persistent, system GMM estimator will display the lowest bias and highest precision (Soto, 2009).

The system GMM estimator requires moment conditions, which are specified on the regression errors. Moment conditions are assumed that the instruments are exogenous. For this, the moments of the errors with the instruments equal to zero. In system GMM estimator, the choice of instruments and regressors in each equation should be carefully considered. Since an equation may be under-identified, exactly identified and over-identified depending on whether the number of instruments in that equation are respectively less than, equal to or greater the regressors to be estimated. For the two-step system GMM, this estimator is more asymptotically efficient than one-step estimator due to using a suboptimal weighting matrix, but it produces the bias of uncorrected standard errors when instrument count is high. In this respect, Roodman (2009) provides a rule of thumb that the number of instruments should be

\section{Empirical results}

First, we examine the nexus of PCI, private investment and economic growth. Second, we take account of the overall $P C I$ in affecting the growth effect of private investment. Last, we examine the growth effects of $P C I$ sub-indices and their interaction with private investment.

\subsection{The nexus of PCI, private investment and economic growth}

In this part, we first focus on testing the growth effects of PCI and private investment. Then, this study uses the mean of PCI of the whole sample as criteria to classify high level or low level of local governance to examine its effects on economic growth. Provinces with below median scores are ranked into the low performing tier; other provinces are in the high performing tier. Table (1) shows that mean $P C I$ score $(\mu)$ is 56.70 in the period of 2005-2013. The two $P C I$ dummy variables are identified:

$$
\begin{array}{ll}
G P P G_{p c i 1}=\alpha_{0}+\alpha_{1} L G P P_{i t-1}+\alpha_{2} D P I_{i t}+\alpha_{3} P C I_{1}+\alpha_{4} Z_{i t}+\left(\gamma_{i}+\varepsilon_{i t}\right), & P C I_{1}<\mu \\
G P P G_{p c i 2}=\alpha_{0}+\alpha_{1} L G P P_{i t-1}+\alpha_{2} D P I_{i t}+\alpha_{3} P C I_{2}+\alpha_{4} Z_{i t}+\left(\gamma_{i}+\varepsilon_{i t}\right), & P C I_{2} \geq \mu
\end{array}
$$

less than the individual dimension $(\mathrm{N})$.

In system GMM estimation, Hansen test shows that instruments are robust but weakened. Therefore, following up Roodman (2009), the pvalue of Hansen statistic is not over 0.700 to accept these instruments. The Arellano-Bond test for autocorrelation has a null hypothesis of no autocorrelation and is applied to differenced error terms. The test for $\mathrm{AR}(2)$ process in the first differences usually rejects the null hypothesis. The test for $\operatorname{AR}(2)$ is more important since it detects autocorrelation in levels.
$P C I_{1} \leq 56.7$ low governance, taking 1, otherwise 0

$P C I_{2}>56.7$ high governance, taking 1, otherwise 0

The following Eq (1) is given by:

The estimated results are shown in Table (2). Model (1) is estimated with $P C I$ and DPI. Model (2) incorporates $P C I_{1}$ and $D P I$, and Model (3) incorporates $\mathrm{PCI}_{2}$ and $\mathrm{DPI}$. The growth effect of overall PCI is positive and significant (Model 1). The coefficient on $P C I_{l}$ is negative and significant, while the coefficient on $\mathrm{PCI}_{2}$ is 
positive and significant (Model 2 and 3). These findings indicate that economic governance has a negative impact on economic growth for provinces with below mean $P C I$ scores, whereas it has a positive impact for provinces with above mean $P C I$ scores, suggesting that provinces with below mean $P C I$ scores should make great efforts to obtain a higher position in PCI ranking for economic growth. These observations support the idea that better economic governance reduces asymmetric information, transaction costs and risks, and therefore has a significant contribution to improve business doing and economic performance. Furthermore, the coefficient on DPI is positive and significant in all specifications, suggesting that private investment has positive effect on economic growth. The estimated results for $L G P P(-i)$, GOVSP, FDI, HC, INFRA, EX, INDUS, and INF are still consistent in all specifications. Hansen test and $\operatorname{AR}(2)$ test show that the estimated results are reliable.

\subsection{Local governance affecting the growth effect of private investment}

Although overall PCI has the positive growth effect, it can matter economic growth when interacted with private investment. We now examine the role of PCI in the relationship between private investment and economic growth. The idea is to test whether provinces with higher PCI improve the growth effect of private investment or do not. Based on the mean of PCI, we generate interaction terms DPI*PCI ${ }_{1}$ and DPI*PCI 2 .

The estimated results are presented in Table (3). Model (1) and (2) incorporate DPI*PCI ${ }_{1}$ and DPI $* \mathrm{PCI}_{2}$, respectively. Except for $\mathrm{HC}$ and INFRA, the results for $\operatorname{LGPP}(-i)$, GOVSP, LABOUR, EX, INDUS, and INF are consistent in all specifications. Hansen test and AR(2) test show that the estimated results are reliable and robust.

Considering Model (1) and Model (2), the coefficient on DPI*PCI ${ }_{1}$ is insignificant, while the coefficient on DPI*PCI 2 is positive and significant. These results show that the quality of local governance is critical for improving the growth effect of private investment. A higher level of PCI is strongly associated with a higher growth effect of private investment. This result is different from the finding of McCulloch et al. (2013), who show that provincial governance is not associated with provincial economic growth in Vietnam.

\subsection{Interaction effects of PCI sub-indices}

We now examine the role of PCI sub-indices in the growth effects of private investment. We focus on interaction terms between nine PCI sub-indices and private investment. In comparison with private investment, interaction terms between PCI subindices and FDI also are considered.

Table 4 indicates the growth effects of DPI and nine PCI sub-indices variables. Model (1) is estimated with DPI*ENTRYCOST. Model (2) incorporates DPI*LANDACESS. Model (3) incorporates DPI*TRANSPA. Model (4) incorporates DPI*TIMECOST. Model (5) incorporates DPI*INFORMALCHARGES. Model (6) incorporates DPI*PROACT. Model (7) incorporates DPI*POLICYBIAS. Model (8) incorporates DPI*LABOTRAIN, and Model (9) incorporates DPI*LEGAL. What PCI sub-indices are significantly influential in domestic investment? The results show that DPI is associated with TIMECOST, INFORMALCHARGES, LANDACESS, TRANSPA and LEGAL, respectively. DPI interacted with TIMECOST and INFORMALCHARGES has a negative growth effect (Model 4 and 5), whereas the growth effect of DPI is strengthened when interacted with LANDACESS, TRANSPA and LEGAL (Model 2, 3 and 9). 


\section{Table 2}

The nexus of PCI, DPI and economic growth: Two-step GMM, 2005-2013

(Dependent variable: Provincial economic growth rate, LGPP - LGPP(-1))

\begin{tabular}{|c|c|c|c|c|c|c|}
\hline \multirow[t]{2}{*}{ Variables } & \multicolumn{2}{|c|}{ (1) } & \multicolumn{2}{|c|}{$(2)$} & \multicolumn{2}{|c|}{ (3) } \\
\hline & Coef & p-value & Coef & p-value & Coef & $p$-value \\
\hline $\log$ of $G P P(-1)$ & -0.093 & $0.000 * * *$ & -0.091 & $0.000 * * *$ & -0.091 & $0.000^{* * *}$ \\
\hline Foreign direct investment (FDI) & 0.005 & $0.000 * * *$ & 0.002 & $0.021 * *$ & 0.002 & $0.028 * *$ \\
\hline Labour (LABOR) & 0.037 & $0.000 * * *$ & 0.023 & $0.000 * * *$ & 0.023 & $0.000^{* * *}$ \\
\hline Human capital (HC) & 0.005 & $0.004 * * *$ & 0.005 & $0.000 * * *$ & 0.005 & $0.000^{* * *}$ \\
\hline Infrastructure (INF) & 0.003 & 0.381 & 0.005 & $0.033^{* *}$ & 0.005 & $0.044^{* *}$ \\
\hline Export $(E X)$ & 0.008 & $0.000 * * *$ & 0.012 & $0.000 * * *$ & 0.012 & $0.000 * * *$ \\
\hline Industry (INDUS) & 0.001 & $0.000 * * *$ & 0.001 & $0.000 * * *$ & 0.001 & $0.000 * * *$ \\
\hline Inflation (INF) & 0.831 & $0.000 * * *$ & 0.807 & $0.000 * * *$ & 0.811 & $0.000 * * *$ \\
\hline Public spending (GOVSP) & 0.001 & $0.000 * * *$ & 0.0007 & $0.026^{* *}$ & 0.0007 & $0.000^{* * *}$ \\
\hline Private investment (DPI) & 0.038 & $0.000 * * *$ & 0.041 & $0.000^{* * *}$ & 0.041 & $0.000 * * *$ \\
\hline$P C I$ & 0.002 & $0.000 * * *$ & & & & \\
\hline$P C I_{1}(P C I<=56.7)$ & & & -0.0002 & $0.000 * * *$ & & \\
\hline $\mathrm{PCI}_{2}(\mathrm{PCI}>56.7)$ & & & & & 0.0002 & $0.000^{* * *}$ \\
\hline
\end{tabular}




\begin{tabular}{|c|c|c|c|c|c|c|}
\hline \multirow[t]{2}{*}{ Variables } & \multicolumn{2}{|c|}{ (1) } & \multicolumn{2}{|c|}{ (2) } & \multicolumn{2}{|c|}{ (3) } \\
\hline & Coef & $p$-value & Coef & $p$-value & Coef & $p$-value \\
\hline Obs & & & & & & \\
\hline Instruments & & & & & & \\
\hline $\mathrm{AR}(2)$ test & & & & & & \\
\hline Hansen test & & & & & & \\
\hline
\end{tabular}

Notes: $(*),(* *),(* * *)$ indicate significant at $10 \%, 5 \%$ and $1 \%$, respectively. 


\section{Table 3}

The growth effects of interactions between PCI and private investment: Two-step GMM, 2005-2013 (Dependent variable: Provincial economic growth rate, LGPP- LGPP(-1))

\begin{tabular}{|c|c|c|c|c|}
\hline \multirow[t]{2}{*}{ Variables } & \multicolumn{2}{|c|}{ Model (1) } & \multicolumn{2}{|c|}{ Model (2) } \\
\hline & Coef & P-value & Coef & P-value \\
\hline $\log$ of GPP $(-1)$ & -0.084 & $0.000 * * *$ & -0.070 & $0.000 * * *$ \\
\hline Foreign direct investment (FDI) & 0.003 & $0.000 * * *$ & 0.002 & $0.010 * *$ \\
\hline Labour (LABOR) & 0.028 & $0.000 * * *$ & 0.033 & $0.000 * * *$ \\
\hline Human capital (HC) & 0.003 & $0.001 * *$ & 0.003 & $0.050 * *$ \\
\hline Infrastructure (INF) & 0.005 & $0.081 *$ & 0.007 & $0.018 * *$ \\
\hline Export (EX) & 0.010 & $0.000 * * *$ & 0.007 & $0.000 * * *$ \\
\hline Industry (INDUS) & 0.001 & $0.000 * * *$ & 0.0009 & $0.000 * * *$ \\
\hline Inflation (INF) & 0.854 & $0.000 * * *$ & 0.962 & $0.000 * * *$ \\
\hline Public spending (GOVSP) & 0.0008 & $0.0038 * *$ & 0.002 & $0.000 * * *$ \\
\hline Domestic private investment (DPI) & 0.033 & $0.005^{* * *}$ & 0.015 & $0.001 * * *$ \\
\hline PCI & 0.003 & $0.000 * * *$ & 0.001 & $0.009 * * *$ \\
\hline $\mathrm{DPI} * \mathrm{PCI}_{1}$ & $\begin{array}{c}0.0000 \\
1\end{array}$ & 0.147 & & \\
\hline $\mathrm{DPI} * \mathrm{PCI}_{2}$ & & & 0.00004 & $0.011 * *$ \\
\hline Obs & & 382 & & \\
\hline Instruments & & 60 & & \\
\hline $\mathrm{AR}(2)$ test & & 0.137 & & \\
\hline Hansen test & & 0.464 & & \\
\hline
\end{tabular}

Notes: $(*),(* *),(* * *)$ indicate significant at $10 \%, 5 \%$ and $1 \%$, respectively. 


\section{Table 4}

The interaction effects of private investment and PCI sub-indices on provincial economic growth: Two-step GMM, 2005-2013

(Dependent variable: Provincial economic growth rate, LGPP- LGPP(-1))

\begin{tabular}{|c|c|c|c|c|c|c|c|c|c|}
\hline Variables & (1) & (2) & (3) & (4) & (5) & (6) & (7) & (8) & (9) \\
\hline & Entrycost & Landaccess & Transpa & Timecost & Informalcharges & Proact & Policybias & Labotrain & Legal \\
\hline $\log$ of $G P P(-1)$ & $-0.097 * * *$ & $-0.054 * * *$ & $-0.074 * * *$ & $-0.070 * * *$ & $-0.073 * * *$ & $-0.099 * * *$ & $-0.099 * * *$ & $-0.094 * * *$ & $-0.100 * * *$ \\
\hline $\begin{array}{l}\text { Foreign direct investment } \\
\text { (FDI) }\end{array}$ & $0.004 * * *$ & $0.002 * *$ & $0.004 * * *$ & $0.003 * * *$ & $0.003 * * *$ & $0.004 * * *$ & $0.002 * *$ & $0.003 * * *$ & $0.004 * * *$ \\
\hline Labour (LABOR) & $0.026 * * *$ & $0.018 * * *$ & $0.029 * * *$ & $0.018 * * *$ & $0.019 * * *$ & $0.034 * * *$ & $0.032 * * *$ & $0.017 * * *$ & $0.030 * * *$ \\
\hline Human capital $(H C)$ & $0.005 * * *$ & $0.004 * * *$ & $0.005^{* *}$ & $0.005^{* * *}$ & $0.003 * * *$ & $0.005 * * *$ & $0.007 * * *$ & $0.006 * * *$ & $0.005 * * *$ \\
\hline Infrastructure (INF) & $-0.023 * * *$ & -0.002 & $-0.031 * * *$ & $-0.012 * * *$ & $-0.008 * *$ & $-0.018 * * *$ & -0.004 & -0.003 & $-0.011 * * *$ \\
\hline Export $(E X)$ & $0.012 * * *$ & $0.011 * * *$ & $0.017 * * *$ & $0.009 * * *$ & $0.012 * * *$ & $0.014 * * *$ & $0.019^{* * *}$ & $0.023^{* * *} *$ & $0.016^{* * * *}$ \\
\hline Industry (INDUS) & $0.001 * * *$ & $0.001 * * *$ & $0.001 * * *$ & $0.001 * * *$ & $0.001 * * *$ & $0.001 * * *$ & $0.001 * * *$ & $0.002 * * *$ & $0.001 * * *$ \\
\hline Inflation (INF) & $0.897 * * *$ & $0.975 * * *$ & $0.910 * * *$ & $0.922 * * *$ & $0.880 * * *$ & $0.873 * * *$ & $0.668 * * *$ & $0.636^{* * *}$ & $0.845^{* * *}$ \\
\hline Public spending (GOVSP) & $0.0004 * *$ & $0.0009 * * *$ & $0.0009^{* * * *}$ & $0.0006^{* * * *}$ & $0.001 * * *$ & $0.0009 * * *$ & $0.0008 * *$ & $0.001 * *$ & $0.0008 * *$ \\
\hline $\begin{array}{l}\text { Domestic private } \\
\text { investment (DPI) }\end{array}$ & $0.045^{* *}$ & $-0.055^{* *}$ & $-0.114 * * *$ & $0.122 * * *$ & $0.133 * * *$ & $0.062 * *$ & $0.053 * *$ & $0.056^{* *}$ & $0.027 * * *$ \\
\hline PCI sub-indices & -0.075 & $-0.373 * * *$ & $-0.719 * * *$ & $0.406^{* * * *}$ & $0.472 * * *$ & 0.030 & 0.082 & 0.027 & $-0.128^{* *}$ \\
\hline$D P I^{*} P C I$ sub-indices & 0.009 & $0.041 * * *$ & $0.093 * * *$ & $-0.046^{* * *}$ & $-0.051 * * *$ & -0.003 & 0.010 & 0.010 & $0.017 * *$ \\
\hline Obs & 372 & 381 & 372 & 384 & 420 & 384 & 383 & 381 & 383 \\
\hline Instruments & 60 & 57 & 59 & 57 & 57 & 57 & 51 & 56 & 58 \\
\hline $\mathrm{AR}(2)$ test & 0.202 & 0.102 & 0.206 & 0.274 & 0130 & 0.158 & 0.100 & 0.120 & 0134 \\
\hline Hansen test & 0.670 & 0.337 & 0.401 & 0.698 & 0.317 & 0.321 & 0.359 & 0.180 & 0.588 \\
\hline
\end{tabular}

Notes: $(*),(* *),(* * *)$ indicate significant at $10 \%, 5 \%$ and $1 \%$, respectively. 
Table 5 indicates the growth effects of FDI and PCI sub-indices. Model (1) is estimated with FDI*ENTRYCOST. Model (2) incorporates FDI*LANDACESS. Model (3) incorporates FDI*TRANSPA. Model (4) incorporates FDI*TIMECOST. Model (5) incorporates FDI*INFORMALCHARGES. Model (6) incorporates FDI*PROACT. Model (7) incorporates FDI*POLICYBIAS. Model (8) incorporates $F D I^{*} L A B O T R A I N$, and model (9) incorporates $F D I^{*} L E G A L$. All these interaction terms are statistically significant. This shows that FDI is strongly associated with all PCI subindices. However, the effect signs of FDI are various, depending on the nature of each PCI sub-indices. For example, FDI in association with ENTRYCOST, TIMECOST, INFORMALCHARGES and POLICYBIAS, respectively, has a significantly negative effect on economic growth (Model 1, 4, 5 and 7). Therefore, under high entry cost for new firms, times cost of regulatory compliance, informal charges, and policy bias, the effect sign of FDI is negative. The reason is, Vietnamese legal system is still not adequate and integrity so that this could lead to confusion and unfairness for the investors. Another aspect of the legal system is a bureaucracy in provincial authorization agencies. It may raise foreign investors' costs of doing business. Therefore, taking account of the growth effect of FDI, Vietnam's provincial governments make economic governance better by reducing entry cost, time cost, informal charges, and policy bias.

Interestingly, FDI in association with LANDACESS, TRANSPA, PROACT, $L A B O T R A I N$ and $L E G A L$, respectively, has a significantly positive effect on economic growth (Model 2, 3, 6, 8 and 9). The more predictable easy access to land, transparency, proactivity of local leadership, sound labor training and fair legal implementation are, the more foreign investments are made and the higher economic growth is. These results are important. In attempting to attract more foreign investors, provincial governments make efforts to improve the business environment. Therefore, policy arenas such as land access, policy transparency, proactivity of leadership, labor training, and legal implementation become decisive factors in provincial FDI attraction and economic growth at Vietnamese provincial level as found by Tran et al. (2009). Policy implication of these results is that foreign investors expand their projects when local authorities have a positive view towards the favorable business environment and make economic governance better.

These results make a good deal of sense. Domestic investors are less sensitive to the quality of provincial economic governance than foreign investors are. Regarding negative effect, foreign investors are significantly affected by entry cost, times cost, informal charges and policy bias, whereas domestic investors are only influenced by time cost and informal charges. As for the positive effect, improving the land access, policy transparency and legal implementation is decisive for both foreign and domestic investors. Interestingly, leadership proactivity, and labor training are positive significant for foreign investors, but insignificant for domestic investors. In short, these findings show that FDI may be a crucial driver in strongly pushing public governance reforms compared to domestic sector in Vietnam as suggested by Dang (2013) and Schaumburg-Müller (2005).

Notably, with the exception of INFRA, the estimated results for all of the variables ( $L G P P$ $(-1), H C, E X, I N D U S$ and INF are consistent in all specifications. First, the growth effect of INFRA is inconsistent. This is because that infrastructure needs much time to be in stable effect of improving growth in very long run. Second, $L G P P(-1)$ has a significant and negative effect, which may be interpreted as suggesting that there may be convergence in economic 
growth among provinces in Vietnam. Third, $H C$ has a positive impact on provincial economic growth, suggesting that human capital is an important factor in determining provincial economic growth. Fourth, exports have also been a significant driver of economic growth in the provinces. This effect on growth $E X$ has a positive and significant impact on provincial economic growth, supporting the view that exports are an important source of scale economies and real productivity gains that help to promote economic growth. Fifth, INDUS has a positive and significant impact on provincial economic growth, suggesting that an increase in the share of industry in gross provincial product has a direct effect on economic growth in the provinces. Sixth, GOVSP positively affects economic growth, implying that government spending has significant contribution to improving provincial economic performance. Lastly, the estimated coefficient for INF is positive and significant, indicating a positive association between inflation and growth during the period under consideration.

\section{Conclusions}

This paper' aim is to contribute to the existing literature on the relationship between local governance, private investment and economic growth. It is conducted based on the context of Vietnam at the provincial level. Data for the study covers 63 provinces in the period 2004-2013. This study has interesting findings.

First, PCI as a proxy for provincial local governance has a significant effect on economic growth. As indicated by the low and high level of PCI, the study finds that provinces with low PCI have the negative effect on provincial economic growth, whereas provinces with high PCI have the positive effect on provincial economic growth. Moreover, the growth effect of private investment is strengthened when interacted with the high level of PCI, and vice versa. Similarly, the results of FDI are enhanced in the presence of the high level of PCI. Therefore, this study suggests that improving local governance leads to increasing the growth effect of incorporating domestic investment. This is to say, local governance plays a critical role in driving private sector resources into economic growth. Therefore, this implies that provincial governments should focus on improving the quality of local governance because it is at the center of public administration reforms taking place in Vietnam.

Second, to find appropriate measures for improving the growth effect of PCI, the study utilizes interaction terms of PCI sub-indices with private investment and FDI. The estimation results are interesting. Private investment in association with time cost and informal charges, respectively is a significantly negative impact on economic growth. Domestic investment in association with land access, policy transparency, and fair legal implementation, respectively is a significantly positive impact on economic growth. Meanwhile, FDI in association with entry cost, time cost, informal charges and policy biases, respectively is a significantly negative impact on economic growth. FDI in association with easy access to land, policy transparency, proactivity of leadership, sound labor training and fair legal implementation, respectively is a significantly positive impact on economic growth. 


\section{Table 5}

The interaction effects of FDI and PCI sub-indices on provincial economic growth: Two-step GMM, 2005-2013

(Dependent variable: Provincial economic growth rate, $L G P P-L G P P(-1)$ )

\begin{tabular}{|c|c|c|c|c|c|c|c|c|c|}
\hline Variables & $\begin{array}{c}(1) \\
\text { Entrycost }\end{array}$ & $\begin{array}{c}(2) \\
\text { Landaccess }\end{array}$ & $\begin{array}{c}\text { (3) } \\
\text { Transpa }\end{array}$ & $\begin{array}{c}\text { (4) } \\
\text { Timecost }\end{array}$ & $\begin{array}{c}(5) \\
\text { Informalcharges }\end{array}$ & $\begin{array}{c}(6) \\
\text { Proact }\end{array}$ & $\begin{array}{c}\text { (7) } \\
\text { Policybias }\end{array}$ & $\begin{array}{c}\text { (8) } \\
\text { Labotrain }\end{array}$ & $\begin{array}{c}(9) \\
\text { Legal }\end{array}$ \\
\hline $\log$ of $G P P(-1)$ & $-0.074 * * *$ & $-0.091 * * *$ & $-0.100 * * *$ & $-0.100 * * *$ & $-0.108 * * *$ & $-0.090 * * *$ & $-0.096 * * *$ & $-0.102 * * *$ & $-0.100 * * *$ \\
\hline Labour (LABOR) & $0.021 * * *$ & $0.056 * * *$ & $0.026 * *$ & $0.065 * * *$ & $0.036^{* * *}$ & $0.055 * * *$ & $0.062 * * *$ & $0.058 * * *$ & $0.041 * * *$ \\
\hline Human capital $(H C)$ & $0.008 * * *$ & $0.008 * * *$ & $0.004 * *$ & $0.007 * * *$ & $0.006^{* * *}$ & $0.007 * * *$ & $0.005^{* * *}$ & $0.011 * * *$ & $0.006^{* * *}$ \\
\hline Infrastructure (INF) & $-0.013 * * *$ & $-0.031 * * *$ & -0.005 & $-0.023 * * *$ & $-0.022 * * *$ & $-0.019 * *$ & $-0.011^{* *}$ & $-0.033 * * *$ & -0.008 \\
\hline Export $(E X)$ & $0.012 * * *$ & $0.017 * * *$ & $0.013 * * *$ & $0.017 * * *$ & $0.017 * * *$ & $0.016 * * *$ & $0.016^{* * * *}$ & $0.019 * * *$ & $0.016 * * *$ \\
\hline Industry (INDUS) & $0.001 * * *$ & $0.0008 * * *$ & $0.001 * * *$ & $0.001 * * *$ & $0.001 * * *$ & $0.001 * * *$ & $0.001 * * *$ & $0.002 * * *$ & $0.0008 * * *$ \\
\hline Inflation (INF) & $0.910 * * *$ & $0.894 * * *$ & $0.872 * * *$ & $0.859 * * *$ & $0.815^{* * *}$ & $0.859 * * *$ & $0.797 * * *$ & $0.688 * * *$ & $0.875^{* * *}$ \\
\hline $\begin{array}{l}\text { Public spending } \\
(\text { GOVSP) }\end{array}$ & $0.0007 * *$ & $0.002 * * *$ & $0.001 * *$ & $0.002 * * *$ & $0.001 * * *$ & $0.002 * * *$ & $0.002 * * *$ & $0.001 * * *$ & $0.002 * * *$ \\
\hline $\begin{array}{l}\text { Domestic private } \\
\text { investment (DPI) }\end{array}$ & $0.040 * * *$ & $0.039 * * *$ & $0.061 * * *$ & $0.026 * * *$ & $0.060 * * *$ & $0.027 * * *$ & $0.030 * * *$ & $0.030 * * *$ & $0.045^{* * *}$ \\
\hline $\begin{array}{l}\text { Foreign direct } \\
\text { investment (FDI) }\end{array}$ & $0.023 * *$ & $-0.003 * * *$ & $-0.049 * * *$ & $0.045 * * *$ & $0.051 * * *$ & $-0.018 * * *$ & $0.020 * *$ & $-0.050 * * *$ & $-0.017 * *$ \\
\hline PCI sub-indices & 0.060 & $-0.182 * * *$ & $-0.199 * * *$ & $0.199 * * *$ & $0.226^{* *}$ & $-0.083 * * *$ & 0.046 & $-0.231 * * *$ & 0.040 \\
\hline$F D I * P C I$ sub-indices & $-0.011 * *$ & $0.027 * * *$ & $0.030 * * *$ & $-0.024 * * *$ & $-0.026 * *$ & $0.012 * * *$ & $-0.010 * *$ & $0.032 * * *$ & $0.010^{* *}$ \\
\hline Obs & 398 & 361 & 384 & 319 & 366 & 361 & 384 & 324 & 398 \\
\hline Instruments & 56 & 56 & 55 & 52 & 56 & 49 & 51 & 52 & 50 \\
\hline $\mathrm{AR}(2)$ test & 0.153 & 0.140 & 0.245 & 0.125 & 0.172 & 0.171 & 0.161 & 0.175 & 0.137 \\
\hline Hansen test & 0.360 & 0.260 & 0.546 & 0.533 & 0.444 & 0.140 & 0.445 & 0.273 & 0.537 \\
\hline
\end{tabular}

Notes: $(*),(* *),(* * *)$ indicate significant at $10 \%, 5 \%$ and $1 \%$, respectively. 
These results show that foreign investors are more sensitive to the quality of provincial economic governance than domestic investors are. Overall, the study provides evidence on the role of PCI in affecting the growth effect of private investment. It is clear from empirical evidence that improving PCI is crucial for improving the growth effect of private investment. Some aspects of PCI sub-indices when interacted with private investment have negative effects on economic growth. It is imperative that provincial governments make economic governance better to promote private investment development

\section{References}

Abu-Bader, S., \& Abu-Qarn, A.S. (2003). Government expenditures, military spending and economic growth: Causality evidence from Egypt, Israel, and Syria. Journal of Policy Modeling, 25(6-7), 567-583.

Acemoglu, D., \& Robinson, J. (2010). The role of institutions in growth and development. Review Economic. Inst., $1(2)$.

ADB. (2005). Viet Nam Private Sector Assessment. Asian Development Bank (Strategy and Program Assessment), Retrieved from http://www.adb.org/documents/viet-nam-private-sector-assessment.

Afonso, A., \& Furceri, D. (2010). Government size, composition, volatility and economic growth. European Journal of Political Economy, 26(4), 517-532.

Aguirre, A. (2017). Contracting institutions and economic growth. Review of Economic Dynamics, 24, $192-217$.

Aiello, F., Iona, A., \& Leonida, L. (2012). Regional infrastructure and firm investment: Theory and empirical evidence for Italy. Empirical Economics, 42(3), 835-862.

Aizenman, J., \& Glick, R. (2006). Military expenditure, threats, and growth. The Journal of International Trade \& Economic Development, 15(2), 129-155.

Altunc, O. F., \& Aydın, C. (2013). The relationship between optimal size of government and economic growth: Empirical evidence from Turkey, Romania and Bulgaria. Procedia-Social and Behavioral Sciences, 92, 6675.

Anderson, T.W., \& Hsiao, C. (1982). Formulation and estimation of dynamic models using panel data. Journal of Econometrics, 18.

Anh, N. N., Minh, N. N., \& Tran-Nam, B. (2016). Corruption and economic growth with a focus on Vietnam. Crime, Law and Social Change, 65(4), 307-324.

Anwar, S., \& Nguyen, L. P. (2010). Absorptive capacity, foreign direct investment-linked spillovers and economic growth in Vietnam. Asian Business \& Management, 9(4), 553-570.

Aparicio, S., Urbano, D., \& Audretsch, D. (2016). Institutional factors, opportunity entrepreneurship and economic growth: Panel data evidence. Technological Forecasting and Social Change, 102, 45-61.

Arellano, M., \& Bond, S. (1991). Some tests of specification for panel data: Monte Carlo evidence and an application to employment equations. Review of Economic Study, 58, 277- 297.

Ascani, A., \& Gagliardi, L. (2015). Inward FDI and local innovative performance. An empirical investigation on Italian provinces. Review of Regional Research, 35(1), 29-47.

Attila, G. (2009). Corruption, taxation and economic growth: Theory and evidence. Recherches Économiques de Louvain, 75(2), 229-268.

Barro, R. (1991). Economic growth in a cross section of countries. Quarterly Journal of Economics, 106, 407443.

Barro, R. J., \& X. Sala-i-Martin (1995). Economic growth. McGraw-Hill, New York. 
Blundell, R., \& Bond, S. (1998). Initial conditions and moment restrictions in dynamic panel data models. Journal of Econometrics, 87(1), 115-143.

Blundell, R., Bond, S., \& Windmeijer, F. (2000). Estimation in dynamic panel data models: Improving on the performance of the standard GMM estimator. Advances in Econometrics. JAI Press, Elsevier Science, Amsterdam.

Braga Tadeu, H. F., \& Moreira Silva, J. T. (2013). The determinants of the long term private investment in Brazil: An empirical analysis using cross-section and a monte carlo simulation. Journal of Economics Finance and Administrative Science, 18, 11-17.

Branch, B. (2014). Institutional economics and behavioral finance. Journal of Behavioral and Experimental Finance, 1, 13-16.

Brousseau, E., Garrouste, P., \& Raynaud, E. (2011). Institutional changes: Alternative theories and consequences for institutional design. Journal of Economic Behavior \& Organization, 79(1-2), 3-19.

Busse, M., \& Hefeker, C. (2007). Political risk, institutions and foreign direct investment. European Journal of Political Economy, 23, 397-415.

Butkiewicz, J. L., \& Yanikkaya, H. (2011). Institutions and the impact of government spending on growth. Journal of Applied Economics, XIV(2), 319-341.

Carboni, O. A., \& Medda, G. (2011). Government spending and growth in a neoclassical model, Mathematics and Financial Economics, 4(4), 269-285.

Carrère, C., \& de Melo, J. (2012). Fiscal spending and economic growth: Some stylized facts. World Development, 40(9), 1750-1761.

Cavicchioli, M., \& Pistoresi, B. (2016). Testing threshold cointegration in Wagner's Law: The role of military spending. Economic Modelling, 59, 23-31.

Chen, S.-T., \& Lee, C.-C. (2005). Government size and economic growth in Taiwan: A threshold regression approach. Journal of Policy Modeling, 27(9), 1051-1066.

Cohen, K. J., Hawawini, G. A., Maier, S. F., Schwartz, R. A., \& Whitcomb, D. K. (1983). Friction in the trading process and the estimation of systematic risk. Journal of Financial Economics, 12, 263-278.

Cooray, A. (2009). Government expenditure, governance and economic growth. Comparative Economic Studies, 51(3), 401-418.

d'Agostino, G., Dunne, J. P., \& Pieroni, L. (2016). Government spending, corruption and economic growth. World Development, 84, 190-205.

Dang, D. A. (2013). How foreign direct investment promotes institutional quality: Evidence from Vietnam. Journal of Comparative Economics, 41(4), 1054-1072.

Dang, V. Q. (2016). The impact of corruption on provincial development performance in Vietnam. Crime, Law and Social Change, 65(4), 325-350.

Daniel, S., \& Roşoiu, I. (2015). Emerging markets queries in finance and business 2014. EMQFB 2014, 24-25 October 2014, Bucharest, Romania The Impact of the Government Revenues and Expenditures on the Economic Growth. Procedia Economics and Finance, 32, 526-533.

De Haan, J. (2007). Political institutions and economic growth reconsidered. Public Choice, 131, 281-292.

Devarajan, S., Swaroop, V., \& Zou, H. (1996). The composition of public expenditure and economic growth. Journal of Monetary Economics, 37(2), 313-344.

Dissou, Y., Didic, S., \& Yakautsava, T. (2016). Government spending on education, human capital accumulation, and growth. Economic Modelling, 58, 9-21.

Duncan, R. (2014). Institutional quality, the cyclicality of monetary policy and macroeconomic volatility. 
Journal of Macroeconomics, 39-Part A, 113-155.

Dzhumashev, R. (2014). Corruption and growth: The role of governance, public spending, and economic development. Economic Modelling, 37, 202-215.

Easterly, W., \& Rebelo, S. (1993). Fiscal policy and economic growth. Journal of Monetary Economics, 32, $417-458$.

Farag, M., Nandakumar, A. K., Wallack, S., Hodgkin, D., Gaumer, G., \& Erbil, C. (2013). Health expenditures, health outcomes and the role of good governance. International Journal of Health Care Finance and Economics, 13(1), 33-52.

Farla, K., de Crombrugghe, D., \& Verspagen, B. (2016). Institutions, foreign direct investment, and domestic investment: Crowding out or crowding in? World Development, 88, 1-9.

Fayissa, B., \& Gill, F. (2016). Revisiting the growth-governance relationship in developing Asian and Oceanic economies. Journal of Economics and Finance, 40(4), 803-816.

Ferris, J. S., \& Voia, M. C. (2015). The effect of federal government size on private economic performance in Canada: 1870-2011. Economic Modelling, 49, 172-185.

Gates, C. L. (2000). Vietnam's economic transformation and convergence with the dynamic ASEAN economies. Comparative Economic Studies, 42, 7-43.

Gerry, C. J., Lee, J.-K., \& Mickiewicz, T. M. (2010). Governance, institutions and growth: Empirical lessons from the post-communist transition. In E. Marelli \& M. Signorelli (Eds.), Economic growth and structural features of transition (pp. 41-59). Palgrave Macmillan UK, London.

Glaeser, E. L., La Porta, R., Lopez-De-Silanes, F., \& Shleifer, A. (2004). Do institutions cause growth? Journal of Economic Growth, 9, 271-303.

Gould, D. M., \& Ruffin, R. J. (1995). Human capital, trade, and economic growth. Weltwirtschaftliches Archiv, 131(3), 425-445.

Greene, J., \& Villanueva, D. (1991). Private investment in developing countries: An empirical analysis. Staff Papers (international Monetary Fund). Palgrave Macmillan Journals, 38(1), 33-58. doi:10.2307/3867034

Gyimah-Brempong, K. (2002). Corruption, economic growth, and income inequality in Africa. Economics of Governance, 3(3), 183-209.

Han, V. X., \& Baumgarte, R. (2000). Economic reform, private sector development, and the business environment in Vietnam. Comparative Economic Studies, 42, 1-30.

Ho, T. S., \& Michaely, R. (1988). Information quality and market efficiency. Journal of Financial and Quantitative Analysis, 23, 53-70.

Jiang, Y., Peng, M.W., Yang, X., \& Mutlu, C. C. (2015). Privatization, governance, and survival: MNE investments in private participation projects in emerging economies. Journal of World Business, 50(2), 294301.

Jongwanich, J., \& Kohpaiboon, A. (2008). Private investment: Trends and determinants in Thailand. World Development, 36(10), 1709-1724.

Kaufmann, D., \& Kraay, A. (2002). Growth without governance. Policy Research Working Paper 2928. World Bank, Washington.

Kiran, B. (2014). Testing the impact of educational expenditures on economic growth: New evidence from Latin American countries. Quality \& Quantity, 48(3), 1181-1190.

Kloosterman, A., \& Schotter, A. (2016). Complementary institutions and economic development: An experimental study. Games and Economic Behavior, 99, 186-205.

Kousky, C., Luttmer, E. F. P., \& Zeckhauser, R. J. (2006). Private investment and government protection. Journal 
of Risk and Uncertainty, 33(1), 73-100.

Krasniqi, B. A., \& Desai, S. (2016). Institutional drivers of high-growth firms: Country-level evidence from 26 transition economies. Small Business Economics, 1-20.

Kshetri, N., \& Dholakia, N. (2011). Regulative institutions supporting entrepreneurship in emerging economies: A comparison of China and India. Journal of International Entrepreneurship, 9(2), 110-132.

Kukeli, A., Fan, C.-M., \& Fan, L.-S. (2006). FDI and growth in transition economies: Does the mode of transition make a difference? Rivista Internazionale di Scienze Economiche e Commerciali, 53(3), 302-322.

Law, S. H., Lim, T. C., \& Ismail, N. W. (2013). Institutions and economic development: A Granger causality analysis of panel data evidence. Economic Systems, 37(4), 610-624.

Lheem, H. G., \& Guo, S. (2004). Political economy of FDI and economic growth in China: A longitudinal test at provincial level. Journal of Chinese Political Science, 9(1), 43-62.

Luo, C. (2007). FDI, domestic capital and economic growth: Evidence from panel data at China's provincial level. Frontiers of Economics in China, 2(1), 92-113.

Malesky, E. J., \& Taussig, M. (2009.) Out of the Gray: The impact of provincial institutions on business formalization in Vietnam. Journal of East Asian Studies, 9(2), 249-290.

Mallick, J. (2013). Private investment in India: regional patterns and determinants. The Annals of Regional Science, 51(2), 515-536.

Marangos, J. (2008). Institutions, development and economic growth. Comparative Economic Studies, 50, 707709.

Markus, S., \& Mendelski, M. (2015). Institutional complementarity, economic performance and governance in the post-communist world. Comparative European Politics, 13(3), 376-404.

McCulloch, N., Malesky, E., \& Duc, N. N. (2013). Does better provincial governance boost private investment in Vietnam? IDS Working Papers, 1-27. doi: 10.1111/j.2040-0209.2013.00414.x

Morozumi, A., \& Veiga, F. J. (2016). Public spending and growth: The role of government accountability. European Economic Review, 89, 148-171.

Morrissey, O., \& Udomkerdmongkol, M. (2012). Governance, private investment and foreign direct investment in developing countries. World Development, 40(3), 437-445.

Nawaz, S. (2015). Growth effects of institutions: A disaggregated analysis. Economic Modelling, 45, $118-126$.

Neyapti, B., \& Arasil, Y. (2016). The nexus of economic and institutional evolution. Economic Modelling, 52, Part B, 574-582.

$\mathrm{Ng}, \mathrm{T} .$, \& Yu, L. (2014). Which types of institutions hinder productivity among private manufacturing firms in China? China Economic Review, 31, 17-31.

Nguyen, T.T., \& van Dijk, M. A. (2012). Corruption, growth, and governance: Private vs. state-owned firms in Vietnam. Journal of Banking \& Finance, 36(11), 2935-2948.

Nguyen, T. V., Le, N. T. B., \& Bryant, S. E. (2013). Sub-national institutions, firm strategies, and firm performance: A multilevel study of private manufacturing firms in Vietnam. Journal of World Business, $48(1), 68-76$.

Nickell, S. (1981). Biases in dynamic models with fixed effects. Econometrica, 49(6).

North, D. C. (1981). Structure and change in economic history. Norton.

North, D. C., \& Thomas, R. P. (1973). The rise of the western world: A new economic history. Cambridge University Press, Cambridge, UK.

North, D. C. (1990). Institutions, institutional change and economic performance. Cambridge University Press, New York. 
Olson, M., Sarna, N., \& Swamy, A. V. (2000). Governance and growth: A simple hypothesis explaining crosscountry differences in productivity growth. Public Choice, 102(3), 341-364.

Omri, A., \& Sassi-Tmar, A. (2015). Linking FDI inflows to economic growth in north african countries. Journal of the Knowledge Economy, 6(1), 90-104.

Oshikoya, T. W. (1994). Macroeconomic determinants of domestic private investment in Africa: An empirical analysis. Economic Development and Cultural Change, 42(3), 573-596.

Peev, E. (2015). Institutions, economic liberalization and firm growth: Evidence from European transition economies. European Journal of Law and Economics, 40(1), 149-174.

Percoco, M. (2014). Quality of institutions and private participation in transport infrastructure investment: Evidence from developing countries. Transportation Research Part A: Policy and Practice, 70, 50-58.

Putterman, L. (2013). Institutions, social capability, and economic growth. Economic Systems, 37, 345-353.

Rajkumar, A. S., \& Swaroop, V. (2008). Public spending and outcomes: Does governance matter? Journal of Development Economics, 86(1), 96-111.

Ramirez, M. D. (2000). The impact of public investment on private investment spending in Latin America: 19801995. Atlantic Economic Journal, 28(2), 210-225.

Romero-Ávila, D., \& Strauch, R. (2008). Public finances and long-term growth in Europe: Evidence from a panel data analysis. European Journal of Political Economy, 24(1), 172-191.

Roodman, D. (2009). How to do xtabond2: An introduction to difference and system GMM in Stata. The Stata Journal, 9(1), 86-136.

Samudram, M., Nair, M., \& Vaithilingam, S. (2009). Keynes and Wagner on government expenditures and economic development: The case of a developing economy. Empirical Economics, 36(3), 697-712.

Sarker, A. E., \& Rahman, M. H. (2007). The emerging perspective of governance and poverty alleviation: A case of Bangladesh. Public Organization Review, 7(2), 93-112.

Schaumburg-Müller, H. (2005). Private sector development in a transition economy: The case of Vietnam. Development in Practice, 15(3/4), 349-361.

Schmidt, U. (2004). Vietnam's integration into the global economy. Achievements and challenges. Asia Europe Journal, 2, 63-83.

Sineviciene, L., \& Railiene, G. (2015). The nexus between government size, tax burden and private investment. Procedia - Social and Behavioral Sciences, 213, 485-490.

Soto, M. (2009). System GMM estimation with a small sample. Barcelona Economics Working Paper Series, No.395.

Tanzi, V., \& Zee, H. H. (1997). Fiscal policy and long-run growth. Staff Papers, 44(2), 179-209.

Tavares, J. (2004). Institutions and economic growth in Portugal: A quantitative exploration. Portuguese Economic Journal, 3, 49-79.

Tran, T. B., Grafton, R. Q., \& Kompas, T. (2009). Institutions matter: The case of Vietnam. The Journal of SocioEconomics, 38(1), 1-12.

Tridico, P. (2007). Institutions, human development and economic growth in transition economies. The European Journal of Development Research, 19, 569-593.

Tromme, M. (2016). Corruption and corruption research in Vietnam: An overview. Crime, Law and Social Change, 65, 287-306.

Tsani, S. (2015). On the relationship between resource funds, governance, and institutions: Evidence from quantile regression analysis. Resources Policy, 44, 94-111.

UNDP. (2009). Institutional reform for public administration in contemporary Viet Nam. United Nations 
Development Programme ( www.undp.org.vn).

UNDP. (2009). Institutional reform for public administration in contemporary Viet Nam. United Nations Development Programme (www.undp.org.vn).

USAID/VNCI-VCCI. (2005). The Vietnam Provincial Competitiveness Index 2007: Measuring economic governance for private sector development.

USAID/VNCI-VCCI. (2009). The Vietnam Provincial Competitiveness Index 2009: Measuring economic governance for business development.

USAID/VNCI-VCCI. (2013). The Vietnam Provincial Competitiveness Index 2012: Measuring economic governance for business development.

Van, V. B., \& Sudhipongpracha, T. (2015). Exploring government budget deficit and economic growth: Evidence from Vietnam's economic miracle. Asian Affairs: An American Review, 42(3).

Vasakui, T., Thai, L. V., \& Van, L. T. P. (2009). Public administration and economic development in Vietnam: Reforming the public administration for the 21 st century. Reference book: Reforming Public Administration in Viet Nam: Current Situation and Recommendations (UNDP in Vietnam).

Villaverde, J., \& Maza, A. (2012). Foreign direct investment in Spain: Regional distribution and determinants. International Business Review, 21(4), 722-733.

Wang, B. (2005). Effects of government expenditure on private investment: Canadian empirical evidence. Empirical Economics, 30(2), 493-504.

Wang, X., \& Wen, Y. (2013). Is government spending a free lunch? Evidence from China. Federal Reserve Bank of St. Louis Working Papers (2013-013A). Retrieved Jan 10, 2015 from http://research.stlouisfed.org/wp/2013/2013-013.pdf

Williamson, O. E. (1981). The economics of organization: The transaction cost approach. American Journal of Sociology, 548-577.

Wilson, R. (2016). Does governance cause growth? Evidence from China. World Development, 79, 138-151.

World Bank. (2015). Making the whole greater than the sum of the parts: A review of fiscal decentralization in Vietnam. The World Bank, Summary Report 2015. Retrieved from http://documents.worldbank.org/curated/en/389051468187138185/Summary-report.

Yıldırım, A., \& Gokalp, M. F. (2016). Institutions and economic performance: A review on the developing countries. Procedia Economics and Finance, 38, 347-359. 